\title{
O OUTRO LADO DE FALAS DE SI. O QUE PODEM ENCENAR
}

\section{THE OTHER SIDE SPEAKS OF ITSELF. WHAT CAN THEY STAGE}

\author{
Paulo César García ${ }^{1}$
}

\section{RESUMO}

Neste texto, reúno considerações de como Michel Foucault teatraliza o discurso. Tratase de um referencial crítico que tomo, a partir do ponto de partida em seu discurso, para ler a dramaturgia contemporânea, objetivando questionar o sujeito em crise. Retratar o lugar para expor a si no gesto de enunciação, criando uma "espécie de monólogo lírico" é proposital para a reflexão de poder falar de si, encenando-se. O espaço da dramaturgia é problematizado por este lugar, tendo em vista a maneira de politizar a assunção da voz pelo corpo que se coloca em cena, tendo o poder de dizer de si e com muitas outras falas que operam como fonte de criação do texto dramático.

Palavras-chave: Sujeito em Crise. Falas de Si. Dramaturgia do Discurso.

\footnotetext{
${ }^{1}$ Professor Titular da Universidade do Estado da Bahia do Curso de Licenciatura em Letras - Núcleo de Estudos Literários e do Programa de Pós-Graduação em Crítica Cultural do Campus II (UNEB). É Doutor em Literatura pela Universidade Federal de Santa Catarina (UFSC) e cumpriu estágio Pós-doutoral na Universidade Federal da Bahia (UFBA). É associado ao GT da ANPOLL Homocultura e Linguagens e do Grupo de Pesquisa Enlace (UNEB) e Cultura e Sexualidade (CUS /UFBA). E-mail: p.garcia@terra.com.br.
} 


\begin{abstract}
In this text, I gather considerations as Michel Foucault dramatizes the speech. This is a critical framework that take from the starting point in his speech, to read contemporary dramaturgy, aiming to question the subject in crisis. Portraying the place to expose themselves in the enunciation gesture, creating a "kind of lyrical monologue" is purposeful for reflection could speak to you, staging itself. The space dramaturgy is questioned by this place, given the way of politicizing the assumption of voice by the body that puts on the scene, having the power to say to each other and with many other lines that operate as a source of creation of the dramatic text.
\end{abstract}

Keywords: Subject in Crisis. Talks to You. Framaturgy Speech. 
Escrever, no fundo, é tentar fazer fluir, pelos canais misteriosos da pena e da escrita, toda substância, não apenas da existência, mas do corpo, nesses traços minúsculos que depositamos sobre o papel. (FOUCAULT, 2016, p. 66)

\section{Escrever, encenar para poder viver.}

Dito pelo enunciado da epígrafe de Michel Foucault, escrevo estas páginas como para absolver os limites da escrita que põe em cena a dramaturgia do discurso. Do que trata a escrita de Foucault quando aponta para a dramaturgia? Primeiro, creio que, no momento em que a fala do pensador francês protagoniza em seus discursos, ela ganha face para encenar a si. O próprio autor de "A ordem do discurso" aponta que: "Escreve-se também para não se ter mais rosto, para se fugir de si mesmo sob sua própria escrita. Escreve-se porque a vida que se tem ao redor, ao lado, fora, longe da folha de papel, [..] se desmancha nesse retangulozinho de papel" (FOUCAULT, 2016, p. 66).

A insurgência mostrada no trecho da referida citação aponta contra o nome do autor, que não se quer conhecido, mas isso é impossível pelas fontes de enunciações de si cabíveis em inúmeros pronunciamentos em debates, palestras, cursos, escritas que mostram a estética de si prevalecendo no foco de enunciação das suas obras. Foucault dá destaque para a linguagem, de como outros espaços visados fazem aparecer possibilidades de falas excluídas em uma frequente procura ética da palavra. O saber cartografado pelas esferas da escrita desmancha medidas quando empreende a experiência de linguagem, como publicado em "As palavras e as coisas". Assim a ótica da escrita revela como os dispositivos do autor de "Vigiar e Punir", "A vontade de saber", "As palavras e as coisas" decorrem do prazer em escrever conferido na questão filosófica, a do "dizer verdadeiro". Na aula inaugural no Collège de France, pronunciada em 1970, Foucault entende a marca corporal se fazer presente no ato de enunciar a si, ou melhor, de uma prática de si que se exercita como forma de revigorar a existência de vidas na fluidez, com a capacidade de o indivíduo criar "determinadas operações sobre si para se transformar e constituir para si uma forma desejada de existência" (ORTEGA, 1999, p.23-24). Falar para Foucault, como diz Philippe Artières (2016, p. 16), "era se 
inscrever, ou não, numa ordem dos, mas era também problematizar, no próprio gesto, essa prática. Falar era reinventar incessantemente um novo teatro, um teatro profundamente político".

A inflexão da fala buscada por Foucault rompe um discurso uníssono em obras como "Arqueologia do saber", com a qual insere o gesto da teatralidade que usa ao praticar a leitura em voz alta. No solo de suas obras, a dramaturgia do discurso é uma prática com a qual introduz diálogo com espectadores, leitores, críticos que são realizadas em eventos, entrevistas, conferências. O poder de falar ocupado numa dimensão física, teatralizando o corpo que se flexiona no movimento da voz é proposital para enunciar o questionamento de evidências. Trata-se de um desmonte de comunicação arbitrária da palavra e exercida até na ironia com mecanismo de desviá-la, tomando lugar para expor a si no gesto de enunciação, ou numa "espécie de monólogo lírico" (FOUCAULT apud ARTIÈRES, 2016, p. 25).

Uma fala autobiográfica que configura a destituição de posição de poder que o autor toma como transmissor da experiência e se cria com a escrita. Visa ao entendimento da doença, da loucura, do crime, da sexualidade, mas no modo como são encenadas, da história da cena que visualiza para falar dos sujeitos ali expostos e em que instância a verdade se coloca para enunciar as subjetividades operadas pela história. Ao formular em que momento as coisas são vistas e não indagadas sobre as verdades do homem moderno, como são mostradas por meio do espetáculo do mundo, Foucault direciona as escritas para um gesto peculiar à dramaturgia. As falas de si encenadas, a partir do modo como as subjetividades se põem, no jogo discursivo, no momento em que enuncia a si, como são produzidas para se constituir como sujeito do discurso, são tentadas na racionalidade que as tornam na cena enunciativa. Para isso, um problema que insere na instância de suas palestras e entrevistas, obras e posicionamentos, como pensador é saber interpelar a individualidade do indivíduo e como o posicionamento do sujeito em crise entra nas malhas do poder (SOUZA, 2015).

Ao ser convidado para o ciclo de "Encontros sobre Dramaturgia Contemporânea", promovido pela "Companhia de Teatro Ateliê Voador", uma ação de atividades nomeada de "Quartas Voadoras”, que acontecem às quartas-feiras mensais, apresentei parte do objetivo deste artigo que, agora reelaborado, busca a relação da dramaturgia com o posicionamento de si no gesto de fala e que ressoa ao sujeito em crise. 
O diálogo com os pensamentos críticos contemporâneos ganha voz ao buscar Foucault em suas fontes, tema do clico da Companhia: "Foucault: Escritas de si e subjetivação do discurso", que tem a intenção de agregar estudos e de debater a dramaturgia nos tempos atuais. Vale enaltecer que esse estudo fora realizado no Pós-doutorado e que se apresenta aqui sumariamente. Djalma Thürler, diretor da Ateliê Voador e Professor da Universidade Federal da Bahia, supervisionou a pesquisa desenvolvida no Programa Multidisciplinar de Pós-Graduação Cultura e Sociedade do Instituto de Humanidades, Artes e Ciência Professor Milton Santos da Universidade Federal da Bahia e também o estudo se insere no grupo de pesquisa Cultura e Sexualidade (Cus), coordenado pelo Professor Dr. Leandro Colling.

O problema da subjetividade abjeta e das inserções que permeiam o espaço do cárcere em "O diário de Genet" (2013) constitui um modo de leitura sobre a qual visa desconstruir a prisão cultural e social, expressando como a noção de abjeto estampa códigos da cultura colonial que vêm à tona com a repercussão de sentidos do imaginário do indivíduo girados para o ser grotesco quando dos atos de injúria, mas, sobretudo, diante dos dispositivos com alta dose de violência aos regimes de poder ou daqueles discursos que reproduzem e se repetem na esteira do estabelecido. Percebe-se que ser revolucionário é um modo de contestação na e pela diferença, não mais sujeito e predicado de uma estrutura montada, mas das suas reversões quando atinge a prática de liberdade.

Tanto a obra "Diário do ladrão" (2005), um teatro de dândis que atuam nas zonas da escrita de modo irônico e crítico ao cultural estabelecido, como a dramaturgia "O diário de Genet", o olhar e o espaço, os sujeitos ali em cena são objetos de análise. Questões discursivas sobre heteronormatividade facultadas na confluência de cisões e rupturas puderam ser retratadas com a leitura dramática em "O diário de Genet", da Companhia Ateliê Voador. Ao procurar outros tempos de verdades, como os que apresentam a própria maneira de politizar a assunção da voz por meio de um corpo que se inscreve, a partir do olhar da obra de Genet, o poder dizer das subjetividades processas por muitas outras falas se alia ao texto dramático. A dramaturgia de Thürler recupera a noção de gesto, tal como pensa Foucault, na qual reverbera o acontecimento do discurso, porque é preciso revelar um real sob atitudes críticas, do 
sujeito-ator mostrando a si, vinculado ao princípio de verdade ao texto que o re-posiciona pela ótica da escrita de Genet.

"O diário de Genet", que estreou em 2013 na Mostra Oficial de Festival de Curitiba - Paraná/Brasil, não trata de uma montagem de um gênero dramático clássico cujo teor de interpretação entre dois personagens não encenam histórias lineares, mas estas são pautadas ao enunciar o que é verdade e não verdade, ao tratar de amores abjetos. $\mathrm{O}$ diário mergulha no campo intertextual em que os recortes da obra de Jean Genet se reconhecem na percepção da fala e são balizadas pela ótica de discursos da contemporaneidade. Os atos apresentados pelos dois intérpretes, os atores Duda Woyda e Rafael Medrado, representam, no espaço do palco, a forma de as subjetividades criadas, no jogo das cenas, serem guiadas na estabilidade da cultura ocidental e patriarcal, de serem atravessadas pela ruptura, com encenações que trazem cicatrizes e seus rompimentos, improvisos que provocam o veio dialógico com a obra de Genet, e permitindo interpelar as abjetas subjetividades, os corpos, as sexualidades.

Djalma Thürler escreve "O diário de Genet" para manter com escritor Francês o risco da fala, acusar as faltas, as desordens, numa linguagem excluída ou linguagem outra, distante do status quo, cabendo a si a exterioridade da loucura, noção especularmente foucaultiana, ao se fazer dizer, criar com o autor de "Nossa Senhora das Flores". Trata de revisitar a subjetividade encenada no diário do outro como recorte crítico aos saberes imperiais, um modo de transversalizar a episteme na voz de Genet por Thürler. Para não dizer de um teatro mimetizado, nada fixado aos conteúdos e retratos historicistas, a forma com a qual cria sujeitos em deriva, Diário do ladrão, de Genet e $O$ diário de Genet, de Thürler, nestes intertextos, é buscada na sinalização de abjetos, quer dizer, na representação do outro que foge da previsibilidade e encontra abertura, a partir do cárcere, para perpassar o ato de si na subversão de ordens e normas que afrontam o poder-dizer, o poder-ser sujeitos de sexualidades livres das amarras e das sociabilidades tacanhas. A leitura dramática de Thürler estiliza vidas, dramaturgia criada em estado-devir, vida que as torna uma obra de arte. Talvez, o sinal da crise do sujeito aí passa pelo livre enunciado de confrontar o corpo do outro, uma herança que se reconhece na voz do outro, que se calca entre o limite do afetivo e do perceptivo, que não para de assombrar o poder falar. 
Procuro dar seguimento ao raciocínio de um gesto de coerção que atinge o sujeito de fala, questionando por onde a subjetividade abjeta protagoniza a voz atuante, agora, vista como encenada no ato de crise, como pensa Pedro de Souza (2015). Crítico do discurso de Michel Foucault, a leitura de Souza toma como base a instigante análise para tratar da "crise na experiência de um sujeito que, ao apontar para o jogo em que é convocado a falar se situa na soleira da porta da ordem tornando visíveis os elementos coercitivos de que a mesma ordem se compõe (SOUZA, 2015, p. 43).

Sendo assim, a crise do sujeito, de acordo com o pensamento de Pedro de Souza (2015), a partir da ótica de Foucault, se estende à literatura. As obras de Caio Fernando Abreu e muitos outros autores literários brasileiros e ocidentais proporcionam reflexivas posições em que personagens enunciam coerções, regularidades, discursos atávicos que modelam o saber de uma maneira e não de outra. Vinte anos se passaram da morte de Caio F., e a "Companhia Ateliê Voador", em homenagem ao escritor de "Morangos Mofados" (2006), produziu o espetáculo "O outro lado de todas as coisas" (2016), de Djalma Thürler. Trata-se de um monólogo lírico encenado por Duda Woyda, trazendo referências textuais do escritor Caio F. Conjugando os textos do autor, a leitura dramática conecta registros, pensamentos, reflexões, diálogos que atingem as encenações de subjetividades em estado-devir, dado o movimento de escutas, de vozes mostradas na dramaticidade, dos espectros que não se curvam a um padrão normativo de viver: "Dos moços, teve aquele bailarino americano em Londres, quatro, cinco meses. Talvez seis. Numa tarde de compras e roubos em Portobello Road me deu de presente um cacto e me deixou plantado até hoje. Esse era amor-de-metrô. Por onde andará? ("Onde andará, Dulce Veiga?". Por onde andará? é das perguntas mais tristes que conheço, sinônimo de se perdeu)" (THÜRLER, 2016, p. 9).

Talvez, em "O outro lado de todas as coisas", escrever para se encenar ou encenar para se dizer é ato alheio, pois todas as vozes que ecoam, no palco, dramatizam discursos que expõem o gesto de enunciar a si, deslocando papéis que giram com a ação de a personagem inserir a vida do outro, introduzindo rumo próprio com a performatização de si e dos demais que atuam no suplemento da teatralização: "Atualmente estou relendo Caio F. Coisa boa é um amigo, encontrar um, reconhecer, como dizia o Vinícius. Como o poeta eu também nunca reconheci amigos 
tomando leite. Adoro encontrá-los pra poder jogar conversa fora, papo vem, papo vai eles me ensinam a viver, a sonhar" (THÜRLER, 2016, p. 8).

A fala do ator citando a releitura em Caio F. permite, no espaço cênico, reescrever, melhor dizer, reencenar, posicionar as marcas textuais do escritor e, quando transposta para os espaços do teatro, espectadores também se deslocam para cena do texto em que o relato do escritor reapresentado por instantes protocola discursos para pensar o outro lado da vida. Assim também, acontece com outros que elege, como Michel Foucault: "Eu nunca tinha lido Foucault, mas gostei do livro em que ele fala dos corpos da gente, o prazer penetrando na política, a erotização da política, a política do desejo" (THÜRLER, 2016, p. 9).

Entre "O diário de Genet" e "O outro lado de todas as coisas", o universo dramático de Thürler repercuti à mercê de um reposicionamento crítico da criação estética ao revisitar o texto do outro, a subjetividade do outro, a fala do outro, especulando os horizontes dos enunciados que lhes afetam e colocam à mostra os perfis de sujeitos frente às interações com os tempos visíveis.

Nos recortes de outras vidas repostas, o diálogo com Caio F. e demais outros autores transparece na nervura das cenas e são por meio delas que viso tratar como o sujeito em crise resplandece no movimento do monólogo. O desejo de encontrar a textualidade de Foucault com a dramaturgia de Thürler ocorre no desdobramento da cena da escrita que ambos dramatizam, principalmente, ao reavivar histórias de vida. Pensar juntos, como retomadas de uma estética de si, não como um quadro representativo, mas produtivo de linguagens que fluem no contato com as verdades em direção aos discursos do sujeito.

\section{Do outro lado de todas as cenas.}

Gostaria de me insinuar sub-repticiamente no discurso que devo pronunciar hoje, e nos que deverei pronunciar aqui, talvez durante anos. Ao invés de tomar a palavra, gostaria de ser envolvido por ela e levado bem além de todo começo possível. Gostaria de perceber que no momento de falar uma voz sem nome me precedia há muito tempo: bastaria, então, que eu encadeasse, prosseguisse a frase, me alojasse, sem ser percebido, em seus interstícios, como se ela me 
houvesse dado um sinal, mantendo-se, por um instante, suspensa (FOUCAULT, 1996, p. 5).

Em "Vigiar e punir", Foucault inicia a escrita no tom teatral quando aborda o suplício de Damiens ${ }^{2}$ que se reveza com a impetuosidade e frieza dos regulamentos corretivos impetrados ao delinquente. No espaço social fechado, percebem-se as estratégias de dispositivos de poder numa ótica teatral em que o panóptico se compõe. Quer dizer, a mecânica do poder na ação de punir abre o parêntese sobre o isolamento, o da fala. A procura de Foucault por Baudelaire, por Bataille, por exemplo, visa à experiência poética, de uma linguagem que não se curva ao ordinário, às ordens prescritas do signo, instalando uma certa "loucura". O isolamento da linguagem com o qual o escritor de "A ordem do discurso" se ampara com a leitura literária é uma forma de associar-se ao outro no espaço em que a fala excluída ganha fórum discursivo em sua escrita. A fala excluída lhe serve de suplemento, "A parte do fogo" (1997), como se refere aos escritos de Blanchot (1997), dentro de episódios que relata de espaços fechados, isolados de onde a escrita oferece meio de análise daqueles em suas redes de poder. É nesse sentido que Watanabe, dramaturgo japonês, ao entrevistar Foucault em sua passagem ao Japão, afirma que não se trata de uma dramaturgia que se instala nesses espaços fechados e "foracluídos", mas de "mise en scène ou da instauração do dispositivo que torna possível uma semelhante dramaturgia do espaço" (FOUCAULT, 2011, p. 226).

A Mise en scène, tal como configura a cena da escrita de Foucault, adere à dramaturgia com aquilo que ele mesmo diz, "interesso-me pelo acontecimento, [...] somos atravessados por processos, movimentos, forças" (FOUCAULT, 2011, p. 224-225). Construir para si um teatro da

\footnotetext{
${ }^{2}$ Registro a cena em que Foucault inicia em "O corpo dos condenados", no primeiro capítulo de "Vigiar e Punir". [Damiens fora condenado, em março de 1757], a pedir perdão publicamente diante da porta principal da Igreja de Paris [aonde devia ser] levado e acompanhado numa carroça, nu, e camisola, carregando uma tocha de cera acesa de duas libras; [em seguida], na dita carroça, na praça de Grève, e sobre um patíbulo que aí será erguido, atenazado nos mamilos, braços, coxas e barrigas das pernas, sua mão direita segurando a faca com que cometeu o dito parricídio, queimada com fogo de enxofre, às partes em que será atenazado se aplicarão chumbo derretido, óleo fervente, piche em fogo, cera e enxofre derretidos conjuntamente, e a seguir seu corpo será puxado e desmembrado por quatro cavalos e seus membros e corpo consumidos ao fogo, reduzidos a cinzas, e suas cinzas lançadas ao vento.(Pièces originales et procédures du procés fait à Robert -François Damiens, 1757, t III, p. 372374).
} 
verdade, uma cena da verdade, uma cena para repensar como o que se tornaram as palavras e as coisas que o colonialismo brotou para o homem moderno, dos domínios, dos regulamentos para o saber, para a sexualidade. $\mathrm{O}$ acontecimento como discurso, como gesto da cena enunciativa torna uma forma de ver e de posicionar-se frente às forças que solicitam refletir a atualidade.

Disso estaria a falar o teatro: "O que está acontecendo, quem somos?" (FOUCAULT, 2011, p. 225), daquilo que o ocupa, falas em potencial frente a um acontecimento, por apreendê-lo e pôr em cena sujeitos indefinidamente no jogo da representação? Ao mesmo tempo, parece que a cena enunciativa do acontecimento que procura, em sua escrita, persiste e falha, atravessa e rompe tempos. Assim sendo, a dramaturgia do discurso de Foucault enseja, entre a submissão e a resistência, ao sujeito que acena a crise, ao encontro de acontecimentos, como bem enaltece Pedro de Souza (2015). Portanto, a crise consiste no ato de problematizar aquilo que tornou possível uma subjetividade historicamente atestável no instante em que faz de si mesmo um problema, como pensa Souza. Quer dizer, "a crise define o sujeito que, sem canônica bipartição entre teoria e prática, se implica ao tempo e ao espaço cênico de sua produção falada e escrita" (SOUZA, 2015, p. 4041).

Leitor de Beckett, o autor de "A história da loucura", segue à risca a dramatização do discurso que ocorre ao acaso, intensificando dados, histórias, falas com maior ou menor ardor. Transcrevo uma passagem do livro "Molloy", como forma de reconstituir os fios que religam ao discurso de Foucault na cena enunciativa e que solicita pensar em que momento o espaço do sujeito acusa a crise:

[...] sempre falo demais ou de menos, o que sempre me faz sofrer, tanto sou apaixonado pela verdade. [...] a longo prazo, meus excessos verbais se revelavam pobreza e inversamente. [...] não me calava, aí está, não me calava... porque dizendo não necessitar de ninguém, não dizia demais, mas uma ínfima parte do que deveria ter dito, que não saberia dizer, deveria ter calado (BECKETT, 1988, p. 31-32).

A cena é movida ao processo de uma linguagem que se exclui, falha no próprio poder do encadeamento da fala e acusa em demasia, acusa o compromisso com a verdade. "Ínfima parte do que deveria ter dito, que não saberia dizer, deveria ter calado" (BECKETT, 1988, p. 31-32) seria 
um escape à ordem do discurso que faz dele um sujeito. Então, o lugar da escrita de Beckett se depara com a escrita de si de Foucault no momento em que o fato de compor a ação, na composição do ato de fala, se estreita com a crise moderna do sujeito. Linguagem, espaço, morte, como preconiza Foucault, enreda a cena de Beckett. Morte que substitui o lugar da loucura e, pela episteme, cria espaço de exclusão. Daí a escrita se contaminar pela linguagem de fora ${ }^{3}$, a que torna possível não ser tocada pelo mesmo, pela semelhança, pela ordem, e os horizontes de dispositivos de poder se instauram como objeto de investigação, aqui, de encenação. Se calar e falar, se os excessos verbais, o dever dizer, o não saber dizer, o ter se calado, são focos de poder que acontecem no plano da realidade, como efeitos de discursos, a performatização do ser na cena de Beckett toma manejo ao manifestar a verdade dentro de um enfoque cultural.

No que toca à arte e aos gêneros artísticos, na insurgência horizontalizada, José da Costa (2012) concebe

A ruptura dos circuitos profissionais mais institucionalizados e estáveis; a sua descentralização e deshierarquização por meios diversos; a multiplicação de acontecimentos, ações e vivências artísticas não compatíveis com os formatos que reproduzem imediatamente os consensos mais habituais, são fatores que ajudam a configurar modos artísticos de resistência aos discursos de verdade e às estruturas de poder no campo da arte (COSTA, 2012, p. 123).

Pensar a dramaturgia do discurso sobre a tônica do acontecimento, como operado na cena da escrita e fala, os modos de controle e as formas de resistências passíveis aos dias de hoje são quebrados com a art-queer, quero dizer, a exteriorização de uma linguagem que mexe com um corpo queer, reconstruído em tempos e espaços diferenciados. Nos anos de 1970, o grupo "Dzi Croquetes" repercuti com alto teor de subversão,

\footnotetext{
${ }^{3} \mathrm{O}$ sentido de fora propõe a permissão para a exterioridade pura, acusada pela linguagem que parte dos paradoxos do limite e da transgressão para falar de si, para falarmos de si mesmos por meio do que se põe para fora, sujeito, poder, corpo e linguagens deixando posicionar por si próprias. O texto Prefácio à transgressão, Foucault retira à transgressão (na linguagem) a carga de pura proibição que surgiria por oposição à carga de pura obediência à norma. Talvez, o ato de ser, tão próximo e tão perto do público, do sujeito que escreve e do seu estar-sujeito do discurso esteja próximo ao que se refere ao "limite e à transgressão". (FOUCAULT, 2001, p. 32).
} 
descentralizando conceitos, inserindo a carga de subjetividade no contra-poder, ao encenar a voz performatizada, disseminando a ilogicidade do sistema operante. A dominação dos corpos e dos sujeitos sai pela culatra, atira longe os desmandos de uma linguagem ordinária e regulatória e gira a cartografia para um espaço de ex-cêntricos. Em tempos passados, também, o "Teatro Oficina", de José Celso Martinez Corrêa, com suas vozes díspares e múltiplas, gera o acontecimento de corpos em riste, avessos aos atritos dos discursos identitários estáveis. Na contemporaneidade dos anos atuais, as dramaturgias "BR Trans", "O Diário de Genet", "O melhor do homem" apontam para o universo foucaultiano em que a sociedade regulada e produzida pelo biopoder, desdobrada por Deleuze, com o conceito de sociedade de controle, é acusada no desnorteio de cenas daquelas montagens. As singularidades do discurso dramatúrgico de hoje acontecem devidamente marcadas pelo pós-disciplinar do poder: "De que forma falar um discurso sobre as identidades sexuais para ser um discurso efetivamente reconhecido? Que indícios de controle operar na cena da dramaturgia no contexto global contemporâneo e linguagem a referir?

Melhor dizer, o campo teórico e crítico com o qual a dramaturgia dialoga enfoca o corpo como estratégia para a cena enunciativa face ao logocentrismo ocidental. Como um teatro rizomático que promove a emergência de forças de contra-poder, a potencialização de vidas pode ser vista como implantada frente a uma série de regras disciplinares, dentro do que Foucault (2016) chama: "tecnologia política do corpo". Dito isto, se produções da dramaturgia constituem no aporte do micropolítico - das subjetividades e dos modos de subjetivação enunciar os estilos de vida retratados por um viés crítico cultural das relações de gêneros e de identidades sexuais, por sua vez, é ponto de chegada para fazer o movimento do contra giro, de poder ver como os gestos direcionados ao poder do corpo se politiza nas cenas teatrais.

Percebe-se em "O diário de Genet" como se traduz a bio-hibridez dos corpos encenados, instados d' "O diário do ladrão", por se fazer criar fora de tudo que poderia contê-lo. A leitura dramática produzida pelos atores é direcionada pela ótica de Djalma Thürler para uma arte-corpo híbrida, em que funda uma espécie de refazendas de falas que se traçam ao lado das marcas da abjet-ação. Termo este que incita ao significado das matrizes que identificam os atos performativos e os rompimentos que se buscam, a partir de um universo de fragilizações da heteronormatividade e, tendo em vista corpos que configuram a reação, 
acenam para sujeitos no movimento de manifestação de si. Então, o sujeito constituído em sua posição de fala, nas cenas da dramaturgia, opera pelo próprio condicionamento crítico frente à criação de si, levado pelo espaço em que fala diante dos efeitos históricos com os quais remete a ação. Abjetar é trazer a reelaboração de si por meio de uma historicidade, de como falar desta, o que e como se aloja na fala e põe o sujeito dentro de um sistema de coerção. Para Pedro de Souza, o momento de crise do sujeito está locado aí na subserviência do indivíduo falante, convertendo-o em posição de sujeito de discurso, "instante cujo efeito crítico é a da própria elaboração de si existindo no seio de uma sociedade de discurso" (SOUZA, 2015, p.43).

Leitura e dramaturgia do discurso, como propõe Foucault, permite atentar para a arte dramática galopada com altivez de substância ética calcada nos escritos que se dobram por meio de outros que os interpelam. Política e teoria se entrelaçam aí na esfera da fala autobiográfica, figura de si enunciada na rearticulação de traços, visões, imagens, poder, corpos que perturbam e exercitam pensar os contextos dos relatos incomuns, de subjetividades que perpassam fluxos. A crise, no espaço do movimento do sujeito de discurso, como se pode observar em Foucault, é aquela em que a fala implica o gesto do infame. As suas funções cerimoniais, como pensa o autor,

[...] vão se apagar pouco a pouco; não terá mais como tarefa manifestar de modo sensível o clamor demasiado visível da força, da graça, do heroísmo, da potência; mas ir buscar o que é o mais difícil de perceber, o mais escondido, o mais penoso de dizer e de mostrar, finalmente o mais proibido e o mais escandaloso. (FOUCAULT, 2003, p. 220-221).

Contudo, é com Serge Doubrovsky (1989) que a memória pessoal reconstituída motiva ao espaço livre da criação: "se eu tento me rememorar, eu me reinvento... sou um ser fictício..." (1989, p. 212). O termo autoficção, a partir da noção Doubrovsky, atende à forma estética, amparando a memória e ficção no jogo atemporal da escrita por reelaborar fontes do passado no presente, mesmo a explicitar a relação autor-narrador-personagem estabelecida com ou não os vínculos de verdade na ficção. Na literatura e na dramaturgia contemporâneas, cinema, teatro, performances, o passo-a-passo do sujeito se depara na difusão para além das fronteiras, descortinando não propriamente o fundo de verdade que demanda da relação ficção e vida e sim dos 
instantes híbridos que instauram heterotopias que se circunscrevem de modo expressivo por intermédio do corpo de alguém, de imagens, de sons, de ecos polifônicos que restauram do "real", autoficcionalizandoos. O que conduz a experiência do autor de "O outro lado de todas as coisas" se liga na difusão da escrita literária de Caio Fernando Abreu como para refletir a vida que relata, com alcance de temas familiares que brotam do estágio de reconhecimento de si mesmo, de signos da arte com a vida real e das relações que aí assimilam do mundo, dando uma personalidade própria à obra. Existe uma certa especulação inclusiva e intrusa do autor com seu tempo projetada com e sobre exposições que se identificam. Caso de textos paralelos que se estreitam pelo perfil mesclado entre o acontecimento do discurso e o imaginário criado.

Fotos, poemas, juras interurbanas. Voltei pra POA e fomos os dois pro Rio. Dois meses lá: o amor resistia forte, robusto, mas ninguém tava a fim de pegar no pesado. Então fazer o quê?! Dividir quarto pensão na Lapa, andar de ônibus, comer espiga de milho e misto quente... Ninguém acreditava em teu-amor-e-uma-cabana, também não era preciso teu-amor-e-um-rolls-royce (seria ótimo), mas pelo menos uma vitrolinha para fazer amor ao som do Bolero de Ravel (amor tem desses lugares-comuns quase inconfessáveis) (THÜRLER, 2016, p. 10).

Como ecos dissonantes, a autoficção se estreita com o espaço cênico criado, podendo ser vista na cena dramatúrgica como um alinhavado de textos que convidam a percepção de falas, imagens, textos, sons, como a que se assiste na belíssima montagem de "O outro lado de todas as coisas". Notam-se dos acordes das memórias, as reapresentadas nas premissas de textualidades de Caio F., a impressão da escrita dramática de Djalma Thürler, que escreve a punho a la gauche, a atitude crítica das verdades nutridas pelas ordens do discurso. O lúdico exercício de transposição em escritas do outro que atrai das falas autorizadas de obras da literatura visa alterar o modo como descose as textualidades do real, referenciando o espaço heterotópico de modo a questioná-lo pelo e como se fala. Se a dramaturgia tem uma gênese, como reflete Foucault, "O outro lado de todas as coisas" produz sua mise-en-scène, recompõe cenas da história da literatura de Caio Fernando Abreu, das vozes audíveis estampadas em cantoras que atingem o autor, o leitor, o espectador, acenando assim para a ideia de uma cartografia em que a subjetividade é visada para se libertar dos assujeitamentos, chegando aos meios dos discursos para dizer a verdade sobre os sujeitos. 
E agora, Caio F.? Não sei muita coisa. Quase nada. Nunca tinha sido tão intenso, nem tão bonito. Nunca tinha tido um jeito assim, tão forever. Não me diga que vai passar, vai passar, vai passar, vai passar. Não me diga que foi ótimo, o que você queria, a eternidade? [...] Posso não saber nada do coração das gentes, mas tenho a impressão, de que, de tudo, o pior é quando entra a segunda parte da letra de "Atrás da porta", ali no quando "dei pra maldizer o nosso lar, pra sujar teu nome, te humilhar”. Chico Buarque é ótimo pra essas coisas. Billie Holiday é ótima pra essas coisas. E Drummond quando ensina que "o amor, caro colega, esse não consola nunca de núncaras" (THÜRLER, 2016, p. 12-13).

Com isso, creio existir um corpus político dramatúrgico que segue na acepção do autoficcional, agenciando ordens reguladas do poder, "enquanto os gestos artísticos que promovem a diferença interna de vozes multidirecionadas no interior de cada fala é que constitui um operador verdadeiramente político", como pensa José da Costa (2012). Assim dito, o teor político da cena teatral dramatúrgica reinscreve o eu performático numa espécie de proceder a-norma. A cena do sujeito do discurso está à mercê da maquinaria do biopoder para a produção de subjetividades na sociedade de controle, operando as linhas de fuga. Como dever fazer para encenar o que cerceia a si, para exercitar a funcionalidade da crise do sujeito na dramaturgia associa ao posicionamento do comando regulatório da fala. Personagem-ator se entrega a si mesmo sem direção, se baseia na ordem do discurso, podendo ser ignorado da função de controlar o fluxo aleatório da fala e oferecer à própria direção de si à qual a própria fala deve se submeter para ganhar continuidade e coerência (SOUZA, 2015). Lembro que em "A ordem do discurso", Foucault abre a cena de fala com a sua aula inaugural e retomo parte do discurso que consta em epígrafe deste texto:

Ao invés de tomar a palavra, gostaria de ser envolvido por ela e levado bem além de todo começo possível. Gostaria de perceber que no momento de falar uma voz sem nome me precedia há muito tempo: bastaria, então, que eu encadeasse, prosseguisse a frase, me alojasse, sem ser percebido, em seus interstícios (FOUCAULT, 1996, p. 5).

Ocupa o seu lugar de fala pelo interstício, momento em que hesita em relação à linguagem que o interpela, mostrando a compulsão com o ato de escrever. Assim como a cena dramática, a mise-en-scène compõem a cena da aula, a mesma que, por fragmentos, pode acontecer o ato em si 
visível, por intermédio de um pequeno gesto que faz olhar o que é visível, fazendo aparecer o que está mais próximo, ligado a nós. Nos interstícios da fala, o gesto de enunciação de si se desloca, como nas imagens do cinema, pois a fala recortada toma dimensão teatral.

Como o que se nota na voz do sujeito-ator em "O outro lado de todas as coisas", as memórias e histórias vividas, contadas e relatadas, ficcionalizadas, reapresentáveis a partir do outro e pelo outro, Caio F., movem o ato de si como acontecimento discursivo. $\mathrm{O}$ autor da dramaturgia pensa, particularmente, na cena vertiginosa em que encandeia os altos e os baixos que irão deslocar todo o percurso cênico da montagem. As cenas imagéticas dobram sobre si mesmas, conclamando para uma autorreflexão, a partir da linguagem do fora. Elas situam como pano de fundo, na requisição ao cinema, com o clássico "Butch Cassidy and the Sundance Kid" (1969), enveredando a cena cinematográfica partilhada pela história de dois personagens, transportando o ato do acontecimento discursivo presentificado pelo áudio, pela imagem e pela voz dos atores:

Bom, eu não sei falar inglês, mas posso garantir a vocês o que antecede essa cena, lembram desse filme? Butchy Cassidy e Sundance Kid (um filme de faroeste de grande sucesso da década de 60, conta a história de uma dupla de bandidos que viviam assaltando bancos, um desses assaltos dá errado). Eles estão em fuga pela mata. A polícia persegue nossos anti-herois, com rastreadores, implacavelmente. Vocês perceberam que eles estão muito tensos, claro, chegaram num precipício, de onde não podem mais voltar. Embaixo, lá embaixo, passa um rio. Os policiais estão a caminho e vão chegar a qualquer momento. É preciso o salto. Sundance diz: "I can not swim", "eu não sei nadar". O abismo enorme, o medo, a vertigem - só de olhar. Mas é preciso. A polícia tá chegando. Não tem volta. Fecham os olhos. Pulam, um pulo vertiginoooooooso - vertiginoso, esse adjetivo precisa ser usado com mais frequência (THÜRLER, 2016, p. 4).

Como por detrás do palco, por assim dizer, a força de interlocução move o percurso da cena teatral em que a história de si promete. Também, o registro do áudio em que aparece a voz da mãe do ator em diálogo com ele, na cena da dramaturgia, chama atenção para o intertexto. Incorpora, do ponto de vista da cena, o estilo peculiar de Caio F. ao produzir falas diferenciadas, diversa da subjetivação do mesmo, interferindo num real im-posto: 
Meu pai, falecido, nunca teve profissão, era um doidivanas desses que não se agarram a nada na vida; e minha mãe, professora de Matemática, mulher batalhadora que tinha o sonho de ver todos os filhos formados na Universidade. Meu nome é Carlos Eduardo de Oliveira Woyda, mas eu nunca fui chamado assim. Nem quando a minha mãe brigava comigo. Desde quando eu ainda tava na barriga dela eu já havia me transformado em Duda, Duda Woyda é meu nome social. Eu nasci em 1984, numa cidade do interior do Paraná, região Noroeste, por onde passam dois rios, o rio Paraná e o rio Ivaí, minha cidade chama-se Parana+Ivaí. Sai de lá em 2006, em direção ao Rio de Janeiro - cidade maravilhosa - onde fiquei dois anos, mais ou menos, e em 2009 eu já queria ser alguém, mudei pra Salvador. Quando eu nasci, pouco tempo depois o Foucault morreu de AIDS aos 57 anos de idade... Às vezes pensam que sou mais velho. Às vezes dizem que sou bonito. Sou hiperativo, mas não tive forças para concluir nem Letras, nem Arte Dramática (THÜRLER, 2016, p. 6-7).

A dramaturgia do discurso de Thürler não se purga aí tão somente dos estranhamentos que a arte está propensa e sim por filtrá-los do processo revertido de pensar a linguagem fora da logicidade de sentidos, da naturalizada forma de condicionar o corpo na pretensão figurativa. Não se trata de serem engajadas, pois as obras do dramaturgo procuram os requisitos ao direito, de não essencializar o gênero, culminando com o devir-sujeito na expressão corrente de si mesmo. Por isso, o ato de interpelar a subjetividade em Caio F. é uma reação que se oferece com o exercício de escrever, visa ao reconhecimento do outro no espaço da escrita: "Adoro poesia. Gosto de Rimbaud. Escrevo cartas. Gosto de escrever e gosto quando gostam das loucuras lúcidas que eu escrevo. Gostaria de escrever mais. Adoro ficar sozinho, ouvir confidências de mulheres, ouvir bolero e samba-canção" (THÜRLER, 2016, p. 7).

Talvez, seja a leitura dramática a que traz a intenção de uma escrita do indecidível, como dar a ver em Derrida (2007). Um outro lado da vida de indecibilidade antenado no gesto de contorcer falas, deixando-as convocar a (im)possibilidade de decidir subjetivar com o direito a falas, sem ser banido no próprio gesto de enunciação. A propriedade do ato mesmo de enunciar as bio-vidas-grafadas e autoficcionalizadas, para que sejam interpretadas, metaforizadas na deferência de escutas, como as das abjetas formas de amar/falar. "Escrevemos para fugir das emoções e para nos ver livres delas" (ABREU apud DIP, 2009, p. 86), escrevia Caio F., quando aludia a escrita como caso de amor, trazendo a 
cena aberta quando reitera falar de si e a maneira como desvela o discurso que ganha eco na literatura.

Do testemunho do escritor literário para a história do ator em cena, ver o diferente é um modo de politizar o desejo, da erotização do desejo. Por meio dos escritos de Caio F. e de Michel Foucault, o acontecimento discursivo em "O outro lado de todas as coisas" acompanha os passos da memória, com as citações de Caio F., enveredadas na identificação de perfis, que remetem ao familiar, a exemplo dos retratos de infância. Vejo assim que os biografemas tal como refletido em Barthes (2008) se integram à cartografia do desejo projetada na encenação de imagens, falas, histórias. O sentido de biografema, para Roland Barthes, constitui uma abordagem reflexiva para pensar a escritura de vida possível à criação de poder se dizer, de querer se viver uma vida. $\mathrm{O}$ termo, dentro de uma perspectiva crítica, direciona para as vidas biografadas, consequência da maneira como é tratada pelas disciplinas. É um modo de leitura que expressa os signos da vida na eficácia de promover não o conhecimento historiográfico, mas a prática de voltar-se para as minúcias, para o ínfimo na vida, suas ambuiguidades e intolerâncias.

Adoro bater fotos. Sou da noite, jogador de buraco, colecionador de revistas eróticas do Zéfiro. Atualmente estou relendo Caio F. Coisa boa é um amigo, encontrar um, reconhecer, como dizia o Vinícius. Como o poeta eu também nunca reconheci amigos tomando leite. Adoro encontrá-los pra poder jogar conversa fora, papo vem, papo vai eles me ensinam a viver, a sonhar. Do pão eu só como o miolo, Spaghetti com molho vermelho, bife, arroz e feijão. Sou viciado em mentos, picolé de morango, bomba de chocolate e crepe Suzette. Goiabada cascão eu não gosto (THÜRLER, 2016, p. 8).

Seja desapropriando da repetição ou do uso da invenção da história, há um outro modo para se fazer encenar por meio de performatividades identitárias, por meio de encalços que se reapresentam. Mostra assim o primado do pensamento crítico ao poder fazer o que e como se pensa o direito ao corpo que se autoficcionaliza. Creio que Derrida (2007) entra no front textual da dramaturgia da Cia Ateliê Voador pelo aporte de procedimentos possíveis para se fazer sujeito: “[...] Indecidível é a experiência daquilo que, estrangeiro, heterogêneo à ordem do calculável e da regra, deve no entanto - é de dever que é preciso falar - entregarse à decisão impossível, tendo embora em conta o direito e a regra" (DERRIDA, 2007, p. 46). 
O espectador, como o leitor, "participa" da cena dramática, vinculando a vida explícita das falas encenadas, na dupla chama existente: pelos ecos de vozes, falas, textos que se propõem na busca de jogos de verdades do sujeito discursivo que também se envolve, é afetado na encenação de si, convidando o leitor/espectador a ser levado ao espaço da verossimilhança, para purgar fatos oriundos do texto ficcionaldramático e com o qual se vê no contexto, como no espelho das cenas narradas. $\mathrm{O}$ espectador assim se afeta na incitação do personagem-ator, porque sente aliar as muitas histórias protagonizadas.

Os recortes das cenas na ordem discursiva dramática despertam o lugar da criação de si, não somente pelo que se representa, pelo que é revelado, mas como faz ao enunciá-lo pelo acontecimento da mise-enscène, trazendo em mente o testemunho do dizer verdadeiro. Percebe-se que a regulação do sistema cultural que se nota na montagem é oriunda da matriz, das personagens dramáticas que agem e se situam nos bastidores das ordens culturais pautadas pela literatura de Caio F. se reencontrando na voz do ator. Como em A ordem do discurso, em que Foucault interpreta a fala encenada, o suplemento da palavra notável da posição do gesto de falar garante a posição de se subjetivar, de poder falar. "O outro lado de todas as coisas" procura o espaço para se desfazer dos retratados im-postos, não somente pela cena de "Butch Cassidy and the Sundance Kid" que quer configurar a parte pelo todo, na vertiginosa cena, mas com todos os cortes de escritas que disseminam das folhas de papel atiçadas no espaço do palco. Talvez, ali esteja o papel ético confiado ao falar de si, Caio F. recitado pela memória livre, na materialização do discurso exposto, no jogo do sujeito falante, que ganha acesso no campo discursivo do espaço da dramaturgia. O manifesto do texto, com a biografia revisitada, desvela Caio F., seus afetos, seus elencos de escritores, cantores, dores, amores.

\section{O outro lado de si: mise-en-scène finale}

"O outro lado de todas as coisas" encena o gesto da crise do sujeito na experiência de tornar a si sujeito de discurso, direcionando para o jogo em que é convocado a falar, posicionado pelas frestas da ordem discursiva, permitindo os visíveis os pontos coercitivos de que a mesma ordem se enuncia, como a que é tomada pela voz da mãe que se contrapõe a de outras que impõem direcionar a vida de seus filhos. Trata do tempo em que relata a personagem de sua própria história e com a 
interferência do áudio que personifica a voz da mãe. O foco de discurso da trama enreda as histórias ali expostas, no tempo do áudio e das performances do ator, constituindo o saber de si e do outro que se põem a partir do catálogo de histórias narradas pela voz internalizada e das ramificações que tornam sujeito a falar: Sou o filho do meio de um tríptico masculino. [...] Coisa boa é um amigo, encontrar um, reconhecer, pra poder confessar determinadas coisas, as velhas manias. Sou do tempo do bambolê. Hoje eu olho em volta, olho e sei que valeu (THÜRLER, 2016, p. 6-9).

Mais uma vez retomo Foucault que acena a questão da aula em "A ordem do discurso": "o que há assim de tão perigoso no fato de as pessoas falarem?” (FOUCAULT, 1996, p. 38). “O outro lado de todas as coisas" explicita os princípios que subjazem à cena alojada numa voz menor (a do filme e a da voz materna, aqui, particularmente,) convertendo o indivíduo falante na posição de discurso. É aí que ressai o momento de crise do sujeito, "instante em que o efeito crítico é a da própria elaboração de si existindo no seio de uma sociedade de discurso" (SOUZA, 2015, p. 43), lembrando que não se trata somente à pergunta "quem sou eu?", mas, sim, a uma outra que se encadeia àquele enunciado: "o que devo fazer?” (SOUZA, 2015, p. 43):

O que que eu faço? Sem você, o que que eu faço? Com que pernas eu devo partir? Uma tarde peguei nas suas mãos e, bem cruel (Ai, como a gente sabe apunhalar com engenho e arte! Crava devagarinho a lâmina, depois revira, dentro da ferida!!), pedi assim: olha bem dentro dos olhos meus e me responde à seguinte pergunta: "Você não me ama mais?" (THÜRLER, 2016, p. 11).

Isso significa que, nas cenas da montagem, o que devo fazer para desregrar horizontes, o que devo fazer pode revelar o prenúncio da enunciação da voz, a liberação de hábitos, conceitos, normas, a ação de não aprisionar, libertar das amarras da regularidade de discursos que prendem o sujeito por um lugar e não percebe outros. Ainda amar para dizer? Como dever amar? Este é o modo como Foucault se prende ao exercício de desvelamento na maneira pela qual o sujeito se coloca como efeito de processos históricos. Este é o modo como as falas vindas de outro lugar, como as de Caio F., ecoam na dramaturgia de Thürler, enunciam sujeitos em crise, o que significa não operar mais no risco de entrar na ordem discursiva, mas de expor o processo pelo qual tem de passar para aceder, alcançar, consentir a uma posição de sujeito nesta 
mesma ordem (SOUZA, 2015, p. 44). Quer dizer, é necessário fazer surgir, aparecer complexas condições em que se produz a subjetivação e aí se encontra o foco que exibe a forma como é constituído o sujeito de saber.

As montagens da dramaturgia de Cia Ateliê Voador colocam personagens para refletir sobre a crise do sujeito em ato, a forma em que a encenação produz vozes que recaem sobre a atitude que dramatiza a crise - quer dizer, bem no estilo foucaultiano - numa atitude de colocar o sujeito não como vítima dos atos de si, e sim como ato produtor de efeito crítico. (SOUZA, 2015, p. 46) e de saber. Significa assim marcar distância e diferença entre os lugares e fazer perceber os pontos em que a subjetividade é o ato de encarceramento que põe os sujeitos a falar, a produzi-los em cena. Por outro lado, pode-se dizer com Foucault, a subjetividade ostentada na dramaturgia é constantemente interpelada porque o sujeito não é a origem de si mesma. Em "A cena da filosofia", Foucault aponta que o sujeito "se forma a partir de um certo número de processos que, não são, esses, da ordem da subjetividade, mas de uma ordem evidentemente muito difícil de nomear e de fazer aparecer, mas mais fundamental e mais originária que o próprio sujeito, não aparecia. (FOUCAULT, 2011, p. 242).

Essas histórias fora de si mesmas, nos contextos culturais dos encarceramentos e nas livres formas de atar/criar em "O diário de Genet, O melhor do homem" e "O outro lado de todas as coisas" mergulham na partilha de vozes que se enumeram: Foucault, Caio F., Genet, Butler, Rolnik, Chico Buarque, Gil, Caetano, Bethânia, Dolores Duran, Elis, todos os elencos que focaliza Thürler, dividindo, na cena intelectiva, as subjetividades na história. Compartilha com esses e demais o que Foucault descreve: "O sujeito tem uma gênese, o sujeito tem uma formação, o sujeito tem uma história, o sujeito não é originário" (FOUCAULT, 2004, p. 590), convertendo a si mesmo, o dramaturgo Thürler, em sujeito de seu pensamento sobre a subjetividade.

Meus amigos que foram abandonados por mim para que eu pudesse mergulhar, voltaram a mil. Tem seus prazeres o fím do amor. Se é patologia, invenção cristã-judaicoocidental-capitalista, ou maya, ego, se é babaquice, piração, se mudou-através-dos-tempos, puro sexo, carência, medo da morte: não interessa. Tenho certeza que estive lá, naquele terreno. Eu garanto, ele existe. Por isso quis falar dele nessa peça. Estou contando a vocês que 
estou fazendo elucubrações sobre o amor porque provavelmente, de uma outra forma, vocês aí que me ouvem, talvez com tédio, talvez com alguma emoção, também estão pensando a mesma coisa. O bicho homem não faz outra coisa a não ser pensar no amor. Amor é palavra que inventamos para dar nome ao Sol abstrato em torno do qual giram nossos pequeninos egos ofuscados, entontecidos, ritmados. A vida toda. Mas se me perguntarem o que quero dizer com isso, não tenho resposta. O que quero dizer é justamente o que estou dizendo. Não estou com pena de mim (THÜRLER, 2016, p. 13).

Daí soltar a voz, soltar a voz é criar, sem a autossuficiência do sujeito de saber e com muitos outros ali dados a ler, a ver, nos gestos de falas encenadas se colocando a si próprio no espaço da dramaturgia. Se há sujeito em crise que se instaura em "O outro lado de todas as coisas", ele se ex-põe pelas forças discursivas em ação, como estratégia de reconstruir a si, reinventar a si, porque não se trata de sair da crise, mas de alcançá-la de modo crítico e paródico, poético em que o eu se refunda.

\section{Referências}

ABREU, Caio Fernando. Morangos Mofados. Rio de Janeiro: Nova Fronteira, 1996.

ARTIÈRES, Philippe. Fazer a experiência da fala. In: Michel Foucault. O belo perigo. Conversa com Claude Bonnefoy. Tradução: Fernando Scheibe. Belo Horizonte: Autêntica, 2016.

BARTHES, Roland. Sade, Fourier, Loyola. São Paulo: Martins Fontes, 2008.

BECKETT, Samuel. Molloy. Tradução de Leo Schlafman. Rio de Janeiro: Nova Fronteira, 1988, pp. 31-32.

BLANCHOT, Maurice. A parte do fogo. Tradução Ana Maria Scherer. Rio de Janeiro:

Rocco, 1997.

BUTCH Cassidy and Sundance Kid. Direção George Roy Hill. Los Anges, USA, Twenty Century Fox, 1966. 
COSTA, José da. Biopolítica e teatro contemporâneo. Lugar comum, Rio de Janeiro, n. 30, p. 121-133, 2012.

DERRIDA, Jacques. Força de lei - o fundamento místico da autoridade. Tradução Leyla Perrone-Moisés. São Paulo: Martins Fontes, 2007.

DIP, Paula. Para sempre teu, Caio F. Cartas, conversas memórias de Caio Fernando Abreu. São Paulo: Record, 2009.

DOUBROVSKY, Serge. Le livre brisé. Paris: Grasset, 1989.

FOUCAULT, Michel. A ordem do discurso. Tradução: Laura Fraga de Almeida Sampaio. São Paulo: Edições Loyola, 1996.

Prefácio à transgressão. In: MOTTA, Manoel Barros (Org.). Ditos e escritos IV Estratégia, poder-saber. Tradução Vera Lúcia Avellar Ribeiro. Rio de Janeiro: Forense Universitária, 2001.

A vida dos homens infames. In: MOTTA, Manoel Barros (Org.). Ditos e escritos III Estética: literatura e pintura, música e cinema. Tradução Inês Autran Dourado Barbosa. Rio de Janeiro: Forense Universitária, 2003.

A cena da filosofia. In: MOTTA, Manoel Barros (Org.). Dito e escrito VII Michel Foucault. Arte, epistemologia, filosofia e história da medicina. Tradução Vera Lucia Avellar Ribeiro. Rio de Janeiro: Forense Universitária, 2011, p. 222-247.

A hermenêutica do sujeito. Tradução Marcio Alves da Fonseca, Salma Tannus Muchail. São Paulo: Martins Fontes, 2004, p. 590.

. Michel Foucault. O belo perigo. Conversa com Claude Bonnefoy. Tradução: Fernando Scheibe. Belo Horizonte: Autêntica, 2016.

GENET, Jean. Diário de um ladrão. Apresentação de Ruth Escobar. Introdução de Jacqueline Laurence e Roberto Lacerda. Rio de Janeiro: Nova Fronteira, 2005.

ORTEGA, Francisco. Amizade e estética da existência em Foucault. Rio de Janeiro: Ed. Graal, 1999. 
SOUZA, Pedro de. Na palavra de Michel Foucault, a cena da crise do sujeito. In: GUERRA, Vânia Maria Lescano; NOLASCO, Edgar Cézar (Orgs). Michel Foucault: Entre o passado e o presente, 30 anos de (des)locamentos.. Campinas/SP: Pontes Editora, 2015, p.39-52.

THÜRLER, Djalma. O outro lado de todas as coisas. Salvador: Companhia de Teatro Ateliê Voador, 2016.

Recebido em 14/11/2016

Aprovado em 13/12/2016 